\title{
PENGARUH KOMUNIKASI DAN DISIPLIN KERJA TERHADAP KINERJA KARYAWAN PADA PT. MITRA BUTTERINDOJAYA
}

\author{
Yeni Ariesa, S.E., M.Si ${ }^{1)}$, Nathania Mulkan ${ }^{2)}$ \\ Fakultas Ekonomi, Universitas Prima Indonesia \\ yeniariesa321@gmail.com ${ }^{1}$,
}

\begin{abstract}
The research was conducted at PT Mitra Butterindo Jaya as the object of the research. PT. Mitra Butterindo Jaya is a company engaged in the distribution of cake ingredients. For this study, researchers only took special research employees at the Medan head office in charge of the sales of PT. Mitra Butterindo Jaya. In interviews and preliminary research observations, there were problems with poor employee performance, such as the number of employees who did not complete their tasks on time, decreased employee accuracy in carrying out their duties and responsibilities within the company and difficulties in cooperation between employees. This also resulted in a decrease in sales experienced by the company. The research method used is a quantitative approach with quantitative descriptive research type. Methods of data collection by interview, distribution of questionnaires and documentation study. The analytical method used is multiple linear regression, coefficient of determination and simultaneous testing ( $F$-test) $(72,231>3,12)$ with value and partially $(t$ test) $(6,730>1,991)$ and $(2,163>1,991)$. The results showed that communication and work discipline simultaneously and partially had a significant positive effect on employee performance with a determination coefficient of $64.3 \%$ which affected employee performance variables.
\end{abstract}

Keywords: communication, work discipline and employee performance

\section{PENDAHULUAN}

\section{Latar Belakang Masalah}

Peranan sumber daya manusia menjadi hal yang harus diperhatikan oleh perusahaan. Sumber daya manusia selalu menjadi aset utama bagi perusahaan agar terus mampu berkembang. Dengan memiliki sumber daya manusia yang berkualitas, perusahaan akan lebih mampu dalam mengembangkan kegiatan bisnis yang mereka miliki. Kinerja karyawan adalah hasil kerja karyawan dalam mengerjakan pekerjaan yang diberikan kepadanya. Kinerja karyawan selalu mendapat perhatian utama dikarenakan kinerja karyawan memegang peranan yang sangat besar bagi kemajuan perusahaan. Komunikasi merupakan proses pengiriman informasi kepada sesama rekan kerja dalam mendukung pekerjaan yang akan dijalankan. Pemberian informasi penting untuk mendukung tercapainya kelancaran bekerja di perusahaan Disiplin adalah ketaatan karyawan kepada norma-norma dan peraturan yang ada 
di perusahaan. Penerapan disiplin sangat dibutuhkan dalam mengatur karyawan di perusahaan. Disiplin akan membuat semua tata cara bekerja dan peraturan yang ada di perusahaan mampu berjalan dengan baik.

PT. Mitra Butterindo Jaya merupakan perusahaan yang bergerak di bidang distribusi bahan-bahan kue. Produk-produk yang didistribusi perusahaan yaitu ragi Magest, Butter Milky, Mie Seblak Instant, Selai nanas Edna dan lainnya. Adapun wilayah pemasaran adalah Medan, dan perusahaan juga melakukan distribusi ke Pekan Baru, Palembang dan kota lain. Untuk penelitian ini, peneliti hanya mengambil penelitian khusus karyawan di kantor pusat medan yang membawahi penjualan PT. Mitra Butterindo Jaya.

Pada wawancara dan pengamatan awal penelitian di dapat permasalahan pada kinerja karyawan yang kurang baik seperti banyaknya karyawan yang tidak menyelesaikan tugasnya tepat waktu, menurunnya ketelitian karyawan dalam melaksanakan tugas dan tanggung jawabnya di dalam perusahaan dan sulitnya kerja sama antar karyawan. Hal ini juga mengakibatkan penurunan penjualan yang dialami oleh perusahaan. Permasalahan pada masalah komunikasi ialah kejelasan komunikasi antara karyawan yang belum berjalan dengan baik, komunikasi yang dilakukan sering tidak tepat dalam penyampaian bahasa dan alur komunikasi yang dilakukan masih sering terjadi kesalahan. Hal ini mengakibatkan sering munculnya kesalahan di dalam menjalankan pekerjaan. Permasalahan pada masalah disiplin kerja ialah tingkat ketidakhadiran karyawan, keterlambatan, pekerjaan yang tidak tepat waktu dan jam pulang kantor yang tidak sesuai peraturan perusahaan. Ini diakibatkan sanksi hukumana yang masih belum jelas, atasan yang belum memberikan keteladanan dalam melaksanakan tugasnya dan balas jasa yang belum memuaskan sehingga banyak karyawan yang mempunyai sikap tidak disiplin.

Berdasarkan latar belakang permasalahan yang terjadi pada perusahaan maka "Pengaruh Komunikasi dan Disiplin Kerja terhadap Kinerja Karyawan pada PT. Mitra Butterindo Jaya".

\section{Identifikasi Masalah}

Identifikasikan masalah sebagai berikut:

1. Komunikasi diantara karyawan yang belum memiliki alur yang jelas dalam mendukung pekerjaan

2. Disiplin kerja karyawan masih rendah dinilai dari karyawan yang masih melakukan pelanggaran peraturan di perusahaan

3. Kinerja karyawan belum maksimal terlihat dari tidak tercapainya target perusahaan 


\section{KAJIAN LITERATUR}

\section{Teori Komunikasi}

Menurut Bangun (2014:359), komunikasi dapat didefinisikan sebagai suatu proses penyampaian informaso dari pengirim (sender) ke penerima pesan (receiver) dengan menggunakan berbagai media yang efektif sehingga pesan tersebut dapat dengan jelas dan mudah dipahami oleh penerima pesan tersebut. Menurut Feriyanto dan Triana (2016:156), komunikasi adalah suatu proses dimana seseorang atau beberapa orang, kelompok, organisasi dan masyarakat menciptakan dan menggunakan informasi agar terhubung dengan lingkungan dan orang lain. Menurut Afandi (2016:34), komunikasi merupakan suatu proses penyampaian suatu pesan dalam bentuk lamnbang bermakna sebagai pikiran dan perasaan berupa ide, informasi, kepercayaan, harapan, himbauan dan sebagai panduan yang dilakukan oleh seseorang kepada orang lain, baik secara langsung secara tatap muka maupun tidak langsung melalui media, dengan tujuan mengubah sikap, pandangan atau perilaku.

\section{Teori Disiplin Kerja}

Menurut Rivai dan Sagala (2013 : 825), disiplin kerja adalah suatu alat yang digunakan oleh para manajer untuk berkomunikasi dengan karyawan agar mereka bersedia mengubah suatu perilaku serta sebagai suatu upaya untuk meningkatkan kesadaran dan kesediaan seseorang menaati semua peraturan perusahaan dan norma-norma sosial yang berlaku.Menurut Sutrisno (2011 : 86), disiplin adalah sikap ketersediaan dan kerelaan seseorang untuk mematuhi dan menaati norma-norma peraturan yang berlaku di sekitarnya. Menurut Hasibuan (2016: 193), kedisiplinan adalah kesadaran dan kesediaan seseorang menaati semua peraturan perusahaan dan norma-norma sosial yang berlaku.

\section{Teori Kinerja Karyawan}

Menurut Moeheriono (2015:95), kinerja merupakan gambaran mengenai tingkat pencapaian pelaksanaan suatu program kegiatan atau kebijakan dalam mewujudkan sasaran, tujuan, visi dan misi organisasi yang dituangkan melaui perencanaan strategis suatu organisasi. MenurutSedarmayanti (2015:50), kinerja juga berarti prestasi kerja, pelaksanaan kerja, pencapaian kerja atau hasil kerja/untuk kerja/penampilan kerja. Menurut Marwarnsyah (2015:228), kinerja adalah pencapaian atau prestasi seseorang berkenaan dengan tugas-tugas yang dibebankan kepadanya.

\section{Teori Pengaruh Komunikasi terhadap Kinerja}

Menurut Bangun (2014:362), komunikasi memiliki peran dalam sebuah organisasi dalam hal agar individu atau kelompok dapat berkinerja dengan baik perlu dipertahankan beberapa macam pengawasan terhadap anggotanya, merangsang anggota untuk dapat 
berkinerja dengan baik dan menyediakan fasilitas dalam pengungkapan emosi, sehingga dapat membuat pilihan-pilihan dalam pengambilan keputusan. Menurut Silalahi (2011:274), melalui komunikasi dapat ditingkatkan motivasi pegawai dengan menjelaskan apa yang harus dikerjakan, seberapa baik yang mereka kerjakan dan apa yang dapat dikerjakan untuk meningkatkan kinerja mereka. Menurut Siswandi (2011:174), di setiap organisasi tipe apapun dan bergerak dibidang apapun maka kehadiran komunikasi mutlak diperlukan. Tidak ada kinerja yang efektif jika mengabaikan komunikasi.

\section{Teori Pengaruh Disiplin terhadap Kinerja}

Menurut Sinambela (2016 : 237), terdapat hubungan yang signifikan di antara variabel kinerja dengan disiplin kerja. Semakin tinggi disiplin kerja seseorang, maka akan semakin tinggi juga kinerja orang tersebut, disadari bahwa sangat banyak variabel yang berhubungan signifikan dengan kinerja pegawai, akan tetapi salah satu penyumbang utama kinerja adalah disiplin kerja. Menurut Darmawan (2013:41), disiplin yang efektif sebaiknya diarahkan kepada perilakunya, dan bukannya kepada karyawan karena alasan untuk pendisiplinan adalah meningkatkan kinerja. Menurut Hartatik (2014 : 185), kedisiplinan harus ditegakkan dalam suatu organisasi, karena tanpa dukungan disiplin personel yang baik, organisasi akan sulit mewujudkan tujuannya. Jadi, dapatlah dikatakan bahwa kedisiplinan merupakan kunci keberhasilan suatu organisasi dalam mencapai tujuan yang telah ditentukan

Tabel I.1

Penelitian Terdahulu

\begin{tabular}{|c|c|c|c|c|}
\hline No & Peneliti & enelitian & $\begin{array}{c}\text { Variabel } \\
\text { Penelitian }\end{array}$ & Hasil Penelitian \\
\hline 1 & $\begin{array}{c}\text { Khasanah } \\
\text { (2016) }\end{array}$ & $\begin{array}{l}\text { Pengaruh } \\
\text { Kepemimpinan, } \\
\text { Disiplin Kerja dan } \\
\text { Komunikasi } \\
\text { terhadap Kinerja } \\
\text { Karyawan (Studi } \\
\text { Karyawan Pada } \\
\text { Bagian Produksi } \\
\text { PT New Merch } \\
\text { Semarang) } \\
\end{array}$ & $\begin{array}{l}\mathrm{X}_{1}= \\
\text { Kepemimpin } \\
\text { an } \\
\mathrm{X}_{2}=\text { Disiplin } \\
\text { Kerja } \\
\mathrm{X}_{3}= \\
\text { Komunikasi } \\
\mathrm{Y}=\text { Kinerja } \\
\text { Karyawan }\end{array}$ & $\begin{array}{l}\text { Secara simultan } \\
\text { Kepemimpinan, disiplin dan komunikasi berpengaruh } \\
\text { positif dan signifikan terhadap kinerja karyawan } \\
\text { Secara parsial } \\
\text { Kepemimpinan, disiplin dan komunikasi berpengaruh } \\
\text { positif dan signifikan terhadap kinerja karyawan }\end{array}$ \\
\hline 2 & $\begin{array}{l}\text { Paruru } \\
(2017)\end{array}$ & $\begin{array}{l}\text { Pengaruh Disiplin } \\
\text { Kerja dan } \\
\text { Kemampuan } \\
\text { Kerja Terhadap } \\
\text { Kinerja Karyawan } \\
\text { PT Air Manado }\end{array}$ & $\begin{array}{l}\mathrm{X}_{1}=\text { Disiplin } \\
\mathrm{X}_{2}= \\
\text { Kemampuan } \\
\text { Kerja } \\
\mathrm{Y}=\text { Kinerja } \\
\text { Karyawan }\end{array}$ & $\begin{array}{l}\text { Secara simultan } \\
\text { Disiplin dan kemampuan kerja berpengaruh positif dan } \\
\text { signifikan terhadap kinerja karyawan } \\
\text { Secara parsial } \\
\text { Disiplin dan kemampuan kerja berpengaruh positif dan } \\
\text { signifikan terhadap kinerja karyawan }\end{array}$ \\
\hline 3 & $\begin{array}{l}\text { Ginting } \\
(2018)\end{array}$ & $\begin{array}{l}\text { Pengaruh Disiplin } \\
\text { Kerja dan } \\
\text { Komunikasi } \\
\text { Terhadap Kinerja } \\
\text { Karyawan di PT } \\
\text { Sekar Mulia } \\
\text { Abadi Medan }\end{array}$ & $\begin{array}{l}\mathrm{X}_{1}=\text { Disiplin } \\
\text { kerja } \\
\mathrm{X}_{2}= \\
\text { Komunikasi } \\
\mathrm{Y}=\text { Kinerja } \\
\text { Karyawan }\end{array}$ & $\begin{array}{l}\text { Secara simultan } \\
\text { Disiplin Kerja dan komunikasi berpengaruh positif dan } \\
\text { signifikan terhadap kinerja karyawan } \\
\text { Secara parsial } \\
\text { Disiplin Kerja dan komunikasi berpengaruh positif dan } \\
\text { signifikan terhadap kinerja karyawan }\end{array}$ \\
\hline
\end{tabular}


Kerangka konseptual yang dapat digambarkan sebagai berikut:

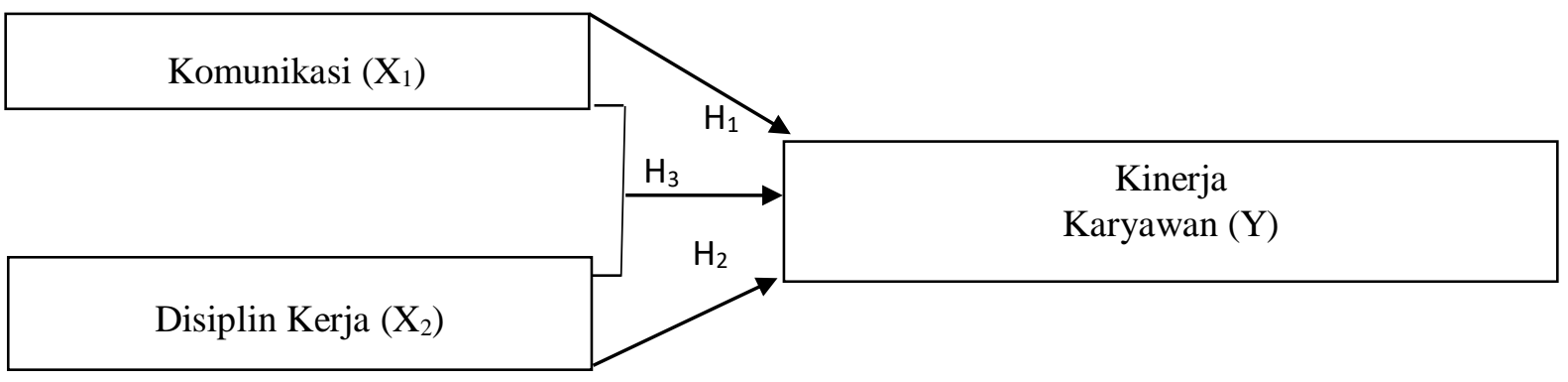

\section{Gambar I.1. Kerangka Konseptual}

Berdasarkan latar belakang dan perumusan masalah serta kerangka pemikiran maka hipotesis dari penelitian ini yaitu :

$\mathrm{H}_{1}$ : Komunikasi berpengaruh terhadap kinerja karyawan di PT. Mitra Butterindo Jaya.

$\mathrm{H}_{2}$ : Disiplin kerja berpengaruh terhadap kinerja karyawan di PT. Mitra Butterindo Jaya.

$\mathrm{H}_{3}$ : Komunikasi dan disiplin kerja berpengaruh terhadap kinerja karyawan di PT. Mitra Butterindo Jaya.

\section{METODE}

Penelitian ini dilakukan pada PT. Mitra Butterindo Jaya yang beralamat di Jalan Komplek Brayan Trade Center No 25 Jalan Serbaguna Helvetia Tengah.Waktu penelitian dimulai sejak bulan Maret 2020 dan direncanakan akan selesai pada bulan September2020. Menurut Sugiyono (2012:13), metode ini sebagai metode ilmiah atau scientific karena telah memenuhi kaidah-kaidah ilmiah yaitu konkrit atau empiris, obyektif, terukur, rasional dan sistemastis. Metode ini berisisi data penelitian berupa angka-angka dan analisis mengunakan statistik

Menurut Sugiyono (2012:29), penelitian deskriptif adalah penelitian statistic yang berfungsi untuk mendeskripsikan atau memebri gambaran terhadap obyek yang diteliti melalui data sampel atau populasi sebagaimana adanya tanpa melakukan analisi dan membuat kesimpulan yang berlaku pada umum. Sedangkan statistik kuantitatif menurut Sugiyono (2012:23) adalah data yang berbentuk angka atau data kualitastif yang diangkakan (skoring). Sifat penelitian yang digunakan dalam penelitian ini adalah explanatory.

Populasi dalam penelitian ini sebanyak 80 karyawan. Sampel berjumlah 80 karyawan. Teknik pengambilan sample menggunakan sampling jenuh. Menurut Sugiyono (2012: 124), sampling jenuh adalah teknik penentuan sampel bila semua anggota populasi digunakan 
sebagai sampel.Untuk uji valid 30 orang di ambil dari PT. Indodaiy Continental berlokasi di Jalan TB. Simatupang Gang Kapur No.28, Sunggal. Pengumpulan data terkait permasalahan yang diteliti oleh peneliti dilakukan dengan cara wawancara responden, kuesioner dan studi dokumentasi. Sumber data penelitian terdiri atas data primer dan data sekunder.

\section{Tabel II.1. Definisi Operasional dan Pengukuran Variabel}

\begin{tabular}{|c|c|c|c|}
\hline Variabel & Definisi & Indikator & $\begin{array}{c}\text { Skala } \\
\text { Pengukuran }\end{array}$ \\
\hline $\begin{array}{l}\text { Komunikasi } \\
\left(\mathrm{X}_{1}\right)\end{array}$ & $\begin{array}{l}\text { Komunikasi adalah suatu proses dimana seseorang atau } \\
\text { beberapa orang, kelompok, organisasi dan masyarakat } \\
\text { menciptakan dan menggunakan informasi agar } \\
\text { terhubung dengan lingkungan dan orang lain. } \\
\text { Menurut Feriyanto dan Triana (2016:156) }\end{array}$ & $\begin{array}{ll}\text { 1. } & \text { Kejelasan (clarity) } \\
\text { 2. } & \text { Ketepatan(accuracy) } \\
\text { 3. } & \text { Konteks (contex) } \\
\text { 4. } & \text { Alur (flow) } \\
\text { 5. } & \text { Budaya (culture) } \\
\text { Menurut Umam (2012:229) }\end{array}$ & Skala Likert \\
\hline $\begin{array}{c}\text { Disiplin Kerja } \\
\left(\mathrm{X}_{3}\right)\end{array}$ & $\begin{array}{l}\text { Disiplin kerja adalah suatu alat yang digunakan oleh } \\
\text { para manajer untuk berkomunikasi dengan karyawan } \\
\text { agar mereka bersedia mengubah suatu perilaku serta } \\
\text { sebagai suatu upaya untuk meningkatkan kesadaran dan } \\
\text { kesediaan seseorang menaati semua peraturan } \\
\text { perusahaan dan norma-norma sosial yang berlaku. } \\
\text { Menurut Rivai dan Sagala }(2013: 825)\end{array}$ & $\begin{array}{ll}\text { 1. } & \text { Teladan pemimpin } \\
\text { 2. } & \text { Balas jasa } \\
\text { 3. Keadilan } \\
\text { 4. Waskat } \\
\text { 5. Sanksi hukuman } \\
\text { Sumber : Hasibuan }(2016: 194)\end{array}$ & Skala Likert \\
\hline $\begin{array}{c}\text { Kinerja Kerja } \\
\text { (Y) }\end{array}$ & $\begin{array}{l}\text { Kinerja adalah pencapaian atau prestasi seseorang } \\
\text { berkenaan dengan tugas-tugas yang dibebankan } \\
\text { kepadanya. } \\
\text { MenurutMawarnsyah }(2015: 228)\end{array}$ & $\begin{array}{ll}\text { 1. } & \text { Jumlah pekerjaan } \\
\text { 2. } & \text { Kualitas Pekerjaan } \\
\text { 3. } & \text { Ketepatan Waktu } \\
\text { 4. } & \text { Kehadiran } \\
\text { 5. } & \text { Kemampuan berkerja sama } \\
\text { Sumber : Bangun }(2014: 233)\end{array}$ & Skala Likert \\
\hline
\end{tabular}

\section{Uji Validitas dan Reliabilitas Instrumen Variabel}

\section{Uji Validalitas}

Menurut Sujarweni (2015:192), uji validitas digunakan untuk mengetahui kelayakan butir-butir dalam suatu daftar pertanyaan dalam mendefenisikan suatu variabel. Dengan kriteria sebagai berikut jika $r_{\text {hitung }}>r_{\text {tabel }}$, maka pertanyaan dinyatakan valid an jika $r_{h i t u n g}<$ $\mathrm{r}_{\text {tabel, }}$ maka pertanyaan dinyatakan tidak valid

\section{Uji Reliabilitas}

Menurut Sujarweni (2015:192), reliabilitas adalah suatu ukuran yang menunjukan sejauh mana hasil pengukuran tetap konsisten bila dilakukan pengukuran dua kali atau lebih terhadap gejala yang sama dengan alat pengukur yang sama pula. Pada penelitian ini menggunakan Cronbach Alpha (a). Uji Reliabilitas dapat dilakukan secara bersama-sama terhadap seluruh butir pertanyaan. Jika nilai alpha $>0,60$ butir pertanyaan tersebut adalah reliabel.

\section{Uji Normalitas}

Menurut Sujarweni (2015:52), uji normalitas bertujuan untuk mengetahui distribusi data dalam variabel yang akan digunakan dalam penelitian. Data yang baik dan layak digunakan dalam penelitian adalah data yang memiliki distribusi normal.

1. Uji Statistik 
Normalitas data dapat dilihat dengan mengunakan uji normal Kolmogorov smirnov yaitu:

1. Jika sig $>0,05$ maka berdistribusi normal

2. Jika sig $<0,05$ maka berdistribusi tidak normal

2. Uji Grafik

Grafik histogram yang membandingkan antara data observasi dengan distribusi yang mendekati distribusi normal. Namun demikian hanya dengan melihat histogram hal ini dapat menyesatkan khususnya untuk jumlah sampel yang kecil. Metode yang lebih handal dengan melihat probability plot yang membandingkan distribusi kumulatif dari distribusi normal. Jika distribusi data residul normal, maka garis yang menggambarkan data sesungguhnya akan mengikuti garis diagonalnya.

\section{Uji Multikolinearitas}

Menurut Sujarweni (2015:185),uji multikolineartitas diperlukan untuk mengetahui ada tidaknya variabel independen yang memilki kemiripan antar variabel independen dalam suatu model. Apabila variabel bebas dinyatakan tidak terjadi multikolinearitas jika TOL (tolerance) $>0,1$ dan VIF $<10$.

\section{Uji Heteroskedastisitas}

Menurut Sujarweni (2015:186), uji heteroskedastisitas bertujuan menguji perbedaan variance residual suatu periode pengamatan ke periode pengamatan yang lain.

1. Uji Grafik

Cara memprediksi ada tidaknya heteroskedastisitas pada suatu model dapat dilihat dengan pola gambar scatter plot, regresi yang tidak terjadi heteroskedastisitas jika titik-titik data menyebar di atas dan di bawah atau di sekitar angka 0, titik-titik data tidak mengumpulkan hanya di atas atau di bawah saja, penyebaran titik-titik data tidak boleh membentuk pola bergelombang melebar kemudian menyempit dan melebar kembali dan penyebaran titik-titik data tidak berpola.

2. Uji statistik

Menurut Sujarweni (2015:226), uji heteroskedastisitas dapat dilakukan dengan mengunakan uji Glejseryaitu dengan menguji tingkat signifikansinya. Kriteria uji Glejser yaitu jika sig > 0,05 maka tidak terjadi heteroskedastisitas dan jika sig $<0,05$ maka terjadi heteroskedastisitas

\section{Model Penelitian}

Mengacu pada tujuan dan hipotesis penelitian, maka model penelitian yang digunakan adalah analisis regresi linear berganda. 
Dengan rumus:

$$
\mathbf{Y}=\mathbf{a}+\mathbf{b}_{1} \mathbf{X}_{1}+\mathbf{b}_{2} \mathbf{X}_{2}+\mathbf{e}
$$

Keterangan:

$$
\begin{array}{ll}
\mathrm{Y} & =\text { Kinerja Karyawan } \\
\mathrm{X}_{1} & =\text { Komunikasi } \\
\mathrm{X}_{2} & =\text { Disiplin } \\
\mathrm{a} & =\text { Konstanta } \\
\mathrm{b}_{1,2,3} & =\text { Koefisien Regresi Variabel Bebas } \\
\mathrm{e} & =\text { Standar error }
\end{array}
$$

\section{Koefisien Determinasi}

Menurut Sujarweni (2015:164), koefisien determinasi $\left(\mathrm{R}^{2}\right)$ digunakan untuk mengetahui presentase perubahan variabel tidak bebas $(Y)$ yang disebabkan oleh variabel bebas $(\mathrm{X})$. Jika koefisien determinasi $\left(\mathrm{R}^{2}\right)$ semakin besar, maka presentase perubahan variabel tidak bebas (Y) disebabkan oleh variabel bebas (X) semakin tinggi.

\section{Pengujian Hipotesis Secara Simultan (Uji-F)}

Menurut Sunyoto (2013:137), uji F digunakan untuk mengetahui pengaruh antara variabel independen terhadap variabel dependen secara bersama-sama. Kriteria penelitian hipotesis pada uji $\mathrm{F}$ ini adalah:

$\mathrm{H}_{0}$ diterima apabila $\mathrm{F}_{\text {hitung }} \leq \mathrm{F}_{\text {tabel }}$ untuk tingkat signifikan $\alpha=5 \%$

$\mathrm{H}_{\mathrm{a}}$ diterima apabila $\mathrm{F}_{\text {hitung }}>\mathrm{F}_{\text {tabel }}$ untuk tingkat signifikan $\alpha=5 \%$

\section{Pengujian Hipotesis Secara Parsial (Uji-t)}

Menurut Sunyoto (2013:135-136), uji t digunakan untuk mengetahui ada tidaknya hubungan atau pengaruh yang berarti (signifikan) antara variabel independen secara parsial terhadap variabel dependen. Dengan kriteria pegambilan keputusannya adalah:

$\mathrm{H}_{0}$ diterima apabila $-\mathrm{t}_{\text {tabel }} \leq \mathrm{t}_{\text {hitung }} \leq \mathrm{t}_{\text {tabel }}($ dengan tingkat signifikan $\alpha=5 \%$ )

$\mathrm{H}_{1}$ diterima apabila $\mathrm{t}_{\text {hitung }}<-\mathrm{t}_{\text {tabel }}$ atau $\mathrm{t}_{\text {hitung }}>\mathrm{t}_{\text {tabel }}$ (dengan tingkat signifikan $\alpha=5 \%$ ).

\section{HASIL DAN DISKUSI}

\section{Analisis Statistik Deskriptif}

Analisis statistik akan menjelaskan nilai dari $n$ sebagai sampel penelitian, nilai minimum sebagai nilai paling rendah, nilai maximum sebagai nilai tertinggi, mean sebagai nilai rata-rata dan standar deviasi. 


\section{Tabel 4.1}

Analisis Statistik Deskriptif

Descriptive Statistics

\begin{tabular}{|l|r|r|r|r|r|}
\hline & \multicolumn{1}{|c|}{$\mathrm{N}$} & Minimum & Maximum & \multicolumn{1}{c|}{ Mean } & Std. Deviation \\
\hline Disiplin & 150 & 12.00 & 29.00 & 18.7267 & 3.69998 \\
Stres & 150 & 12.00 & 29.00 & 21.8267 & 3.70696 \\
Kompensasi & 150 & 11.00 & 28.00 & 20.9733 & 3.77549 \\
Kinerja & 150 & 11.00 & 28.00 & 20.3467 & 3.54073 \\
Valid N (listwise) & 150 & & & & \\
\hline
\end{tabular}

Sumber : Hasil Penelitian, 2020 (Data diolah)

Pada hasil dari SPSS akan menjelaskan nilai dari keempat variabel yang diuji pada analisis statistik deskriptif yaitu variabel disiplin, stres dan kompensasi terhadap kinerja. Penjelasan untuk tabel yang diuji dari SPSS dapat dilihat untuk variabel disiplin dengan nilai sebanyak 150 responden sejumlah mean sebesar 18,7267 dengan nilai nilai paling kecil 12 dan nilai paling besar 29 dengan standard deviasi 3,69998. Dari hasil tabel yang diuji dari SPSS dapat dilihat untuk variabel stres dengan nilai sebanyak 150 responden sejumlah mean sebesar 21,8267 dengan nilai paling kecil 12 dan nilai paling besar 29 dengan standard deviasi 3,70696. Dari hasil tabel yang diuji dari SPSS dapat dilihat untuk variabel kompensasi dengan sampel sebanyak 150 responden sejumlah mean sejumlah 20,9733 dengan nilai paling kecil 11 dan nilai paling besar 28 satuan dengan standard deviasi 3,77549. Dari hasil tabel yang diuji dari SPSS dapat dilihat variabel kinerja dengan nilai sebanyak 150 responden sejumlah mean sebesar 20,3467 dengan nilai nilai paling kecil 11 dan nilai paling besar 28 satuan dengan standard deviasi 3,54073.

\section{Hasil Uji Asumsi Klasik}

Uji asumsi klasik yang digunakan dalam penelitian ini terdiri dari uji normalitas, uji multikolinearitas, uji heterokedastisitas.

\section{Uji Normalitas}

Uji normalitas akan dijelaskan menggunakan grafik histogram dan grafik normal $p$ - $p$ plot.

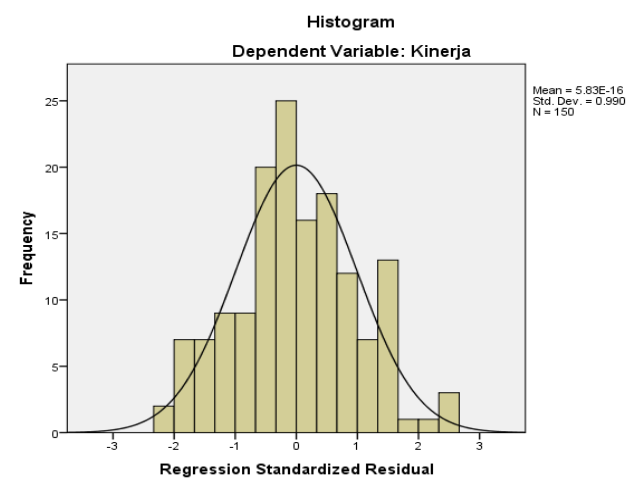

Gambar 4.1 Uji Normalitas Histogram

Sumber : Hasil Penelitian, 2020 (Data diolah) 
Dari uji normalitas histogram, terlihat bahwa garis mengikuti grafik dan membentuk pola lonceng yang berkorelasi baik, sehingga diartikan sudah memenuhi asumsi normalitas.

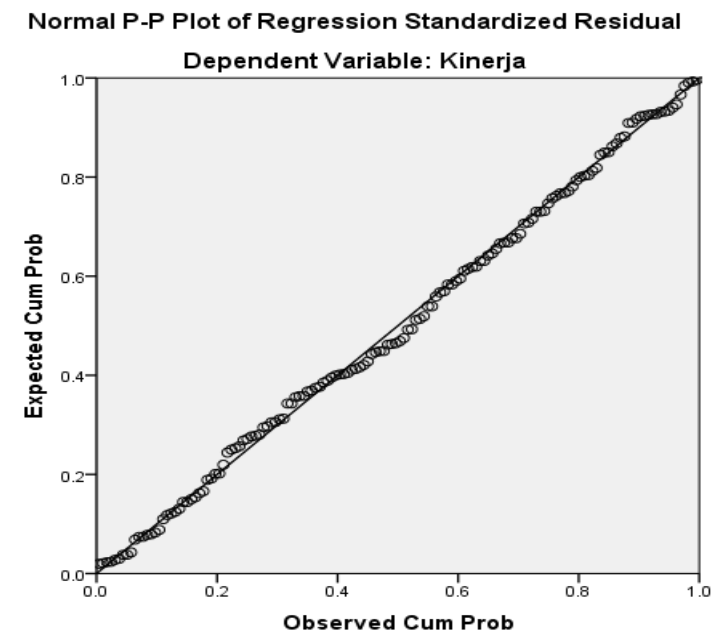

Gambar 4.2 Uji Normalitas P-P Plot

Sumber : Hasil Penelitian, 2019 (Data diolah)

Dari uji normalitas p-p plot, terlihat garuis diikuti oleh titik-titik yang sejajar dan berada disekitar garis diagonal. Hal ini memenuhi kriteria pemahaman bahwa garis memenuhi asumsi normalitas. Langkah selanjutnya yaitu melakukan uji Kolmogorov Smirnov.

Tabel 4.2

Uji Normalitas One Sample Kolmogorov Smirnov One-Sample Kolmogorov-Smirnov Test

\begin{tabular}{|c|c|c|}
\hline & & $\begin{array}{c}\text { Unstandardized } \\
\text { Residual }\end{array}$ \\
\hline $\begin{array}{l}\text { N } \\
\text { Normal Parameters }{ }^{a, b} \\
\text { Most Extreme Differences } \\
\text { Test Statistic } \\
\text { Asymp. Sig. (2-tailed) }\end{array}$ & $\begin{array}{l}\text { Mean } \\
\text { Std. Deviation } \\
\text { Absolute } \\
\text { Positive } \\
\text { Negative }\end{array}$ & $\begin{array}{r}150 \\
.0000000 \\
2.51882139 \\
.038 \\
.038 \\
-.031 \\
.038 \\
.200^{c, d}\end{array}$ \\
\hline
\end{tabular}

a. Test distribution is Normal.

b. Calculated from data.

c. Lilliefors Significance Correction.

d. This is a lower bound of the true significance.

Sumber : Hasil Penelitian, 2020 (Data diolah)

Dari hasil uji, dapat diberikan nilai dari uji normalitas memiliki nilai signifikansi 0,200 dan hal ini memperlihatkan bahwa hasil uji berasumsi normal. 


\section{Uji Multikolinearitas}

Dari uji multikolinearitas, dapat diuji dengan membandingkan nilai dari tolerance dan VIF sesuai dengan kriteria pada multikolinearitas.

Tabel 4.3

Uji Multikolinearitas

\section{Coefficients $^{\mathrm{a}}$}

\begin{tabular}{|ll|r|c|}
\hline \multirow{2}{*}{ Model } & \multicolumn{2}{|c|}{ Collinearity Statistics } \\
\cline { 3 - 4 } & & Tolerance & \multicolumn{1}{c|}{ VIF } \\
\hline 1 & (Constant) & & \\
& Disiplin & .886 & 1.128 \\
& Stres & .839 & 1.192 \\
& Kompensasi & .937 & 1.067 \\
\hline
\end{tabular}

a. Dependent Variable: Kinerja

Sumber : Hasil Penelitian, 2020 (Data diolah)

Dari hasil uji variabel menunjukkan bahwa nilai tolerance untuk variabel bebas disiplin sebesar 0,886 >0,1, variabel bebas stres sebesar 0,839>0,1 dan variabel bebas kompensasi sebesar 0,937 > 0,1 sedangkan nilai VIF untuk variabel bebas disiplin sebesar $1,128<10$, variabel bebas stres kerja sebesar 1,192 < 10 dan variabel bebas disiplin kerja sebesar $1,067<10$ bahwa tidak terjadi korelasi antar variabel bebas antara disiplin, stres dan kompensasi.

\section{Uji Heterokedastisitas}

Pada uji heterokedastisitas, akan dilakukan melalui pengujian grafik scatterplot dan uji glejser.

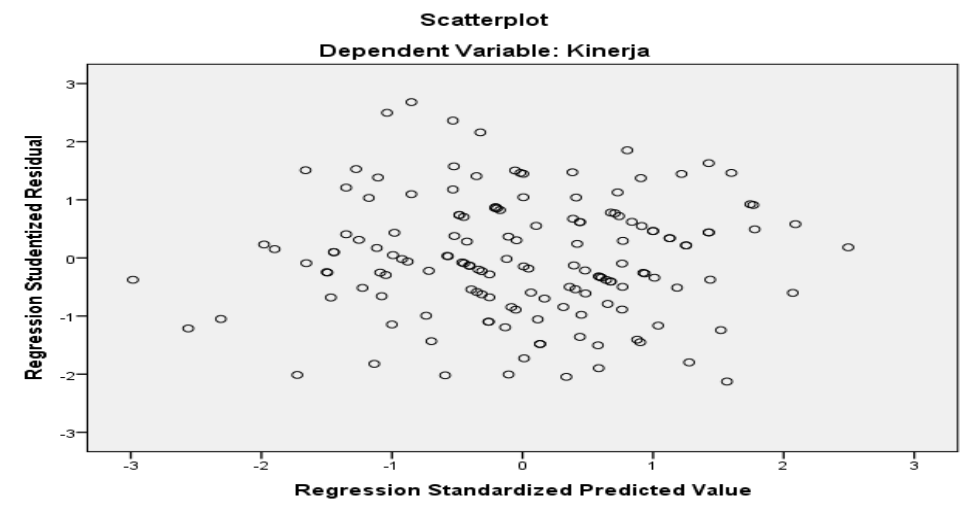

Gambar 4.3 Grafik Scatterplot

Sumber : Hasil Penelitian, 2020 (Data diolah)

Hasil uji pada grafik scatterplot, terlihat bahwa data menyebar dan tidak membentuk pola yang beraturan (acak) sehingga dapat diberikan kesimpulan bahwa data dinyatakan tidak terjadi gejala heterokedastisitas. Untuk langkah berikutnya, maka dilakukan uji glejser secara statistik untuk melihat pemahamannya. Pemahaman dasar yang dapat diberikan jika nilai lebih besar dari 0,05 maka dinyatakan layak dalam uji yang digunakan. 
Tabel 4.4

UjiGlejser

Coefficients $^{\mathrm{a}}$

\begin{tabular}{|c|c|c|c|c|c|c|}
\hline \multirow[b]{2}{*}{ Mode } & & \multicolumn{2}{|c|}{ Unstandardized Coefficients } & $\begin{array}{l}\text { Standardized } \\
\text { Coefficients }\end{array}$ & \multirow[b]{2}{*}{$\mathrm{t}$} & \multirow[b]{2}{*}{ Sig. } \\
\hline & & $B$ & Std. Error & Beta & & \\
\hline \multirow[t]{4}{*}{1} & (Constant) & 1.817 & 1.001 & & 1.816 & .071 \\
\hline & Disiplin & .011 & .036 & .027 & .311 & .757 \\
\hline & Stres & .000 & .037 & -.001 & -.010 & .992 \\
\hline & Kompensasi & -.001 & .034 & -.002 & -.019 & .985 \\
\hline
\end{tabular}

a. Dependent Variable: absut

Sumber : Hasil Penelitian, 2020 (Data diolah)

Setelah melalui hasil dari SPSS, masing masing variabel memiliki nilai lebih besar dari 0,05 untuk nilai signifikannya. Pada variabel disiplin 0,757>0,05, variabel stres 0,992> 0,05 , variabel kompensasi 0,985>0,05. Sehingga dapat diberikan hasil bahwa tidak adanya gejala heterokedastisitas yang terjadi.dan memenuhi kriteria asumsi klasik.

\section{Hasil Analisis Data Penelitian}

\section{Model Penelitian}

Pada analisis ini akan menjelaskan nilai dari regresi linier berganda yang digunakan pada tabel $B$ dalam hasil SPSS berikut ini :

Tabel 4.5

\section{Analisis Linier Berganda}

Coefficients

\begin{tabular}{|ll|r|r|r|r|r|}
\hline \multirow{2}{*}{ Model } & \multicolumn{4}{|c|}{$\begin{array}{c}\text { Standardized } \\
\text { Coefficients }\end{array}$} & \\
\cline { 3 - 5 } & & \multicolumn{2}{|c|}{ Unstandardized Coefficients } & \multicolumn{1}{c|}{ Beta } & \multicolumn{1}{c|}{ Sig. } \\
\hline 1 & (Constant) & .998 & 1.664 & & .600 & .549 \\
& Disiplin & .201 & .060 & .210 & 3.362 & .001 \\
& Stres & .431 & .061 & .451 & 7.014 & .000 \\
& Kompensasi & .295 & .057 & .314 & 5.167 & .000 \\
\hline
\end{tabular}

a. Dependent Variable: Kinerja

Sumber : Hasil Penelitian, 2020 (Data diolah)

\section{Kinerja Karyawan $=$ 0,998 + 0,201 Disiplin + 0,431 Stres + Kompensasi 0,295}

Makna dari persamaan regresi linier berganda diatas adalah :

1. Constant sejumlah 0,998 memberikan pemahaman jika disiplin, stres dan kompensasi tidak ada atau konstan maka kinerja karyawan sebesar 0,998satuan.

2. Model disiplin sebesar 0,201 dan bernilai positif, dan memiliki arti setiap kenaikan disiplin 1 satuan akan peningkatan nilai dari kinerja karyawan sebesar 0,201 satuan.

3. Model stres sebesar 0,431 dan bernilai positif, dan memiliki arti kenaikan stres 1 satuan akan menyebabkan peningkatan nilai dari kinerja karyawan sebesar 0,431 satuan. 
4. Model kompensasi sebesar 0,295 dan bernilai positif, dan memiliki arti kenaikan kompensasi 1 satuan akan menyebabkan peningkatan nilai dari kinerja karyawan sebesar 0,295.

\section{Koefisien Determinasi Hipotesis}

Pada koefisien determinasi menjelaskan nilai dari Adjusted $R$ Square yang akan menjelaskan pengaruh dari variabel independen ke variabel dependen.

\section{Tabel 4.6}

\section{Uji Koefisien Determinasi}

Model Summaryb

\begin{tabular}{|l|r|r|r|c|}
\hline Model & $\mathrm{R}$ & $\mathrm{R}$ Square & $\begin{array}{c}\text { Adjusted R } \\
\text { Square }\end{array}$ & $\begin{array}{c}\text { Std. Error of the } \\
\text { Estimate }\end{array}$ \\
\hline 1 & $.703^{\mathrm{a}}$ & .494 & .484 & 2.54457 \\
\hline
\end{tabular}

a. Predictors: (Constant), Kompensasi, Disiplin, Stres

b. Dependent Variable: Kinerja

Sumber : Hasil Penelitian, 2020 (Data diolah)

Dengan persentase nilai Adjusted R Square sebesar 48,4. Diberikan arti bahwa koefisien determinasi memiliki nilai sebesar $48,4 \%$ dan dapat diberikan kesimpulan bahwa variabel yang diteliti mempengaruhi variabel $48,4 \%$. Variabel stres, kompensasi dan disiplin mempengaruhi variabel kinerja sebesar $48,4 \%$. Sedangkan sisanya sebesar $51,6 \%$ dijelaskan oleh variabel lain yang tidak diteliti pada penelitian ini, seperti deskripsi pekerjaan, komunikasi kerja, punishment dan sebagainya.

\section{Pengujian Hipotesis Secara Simultan}

Pada uji ini akan menunjukkan nilai pengujian variabel secara simultan (bersamasama) antara variabel independen terhadap variabel dependen.

Tabel 4.7

Uji Simultan (Uji F)

ANOVA $^{\mathrm{a}}$

\begin{tabular}{|ll|r|r|r|r|r|}
\hline Model & & Sum of Squares & \multicolumn{1}{|c|}{ df } & Mean Square & F & Sig. \\
\hline 1 & Regression & 922.649 & 3 & 307.550 & 47.499 & $.000^{\mathrm{b}}$ \\
& Residual & 945.325 & 146 & 6.475 & & \\
& Total & 1867.973 & 149 & & & \\
\hline
\end{tabular}

a. Dependent Variable: Kinerja

b. Predictors: (Constant), Kompensasi, Disiplin, Stres

Sumber : Hasil Penelitian, 2020 (Data diolah)

Penyusunan uji dilakukan dengan menghasilkan nilai F sejumlah 47,499. Nilai 150-4 = 146 dengan penentuan sampel sebesar 146 orang untuk melihat nilai $\mathrm{F}$ dengan probabilitas 0,05. Maka dapat ditentukan nilai $F_{\text {tabel }}$ adalah 3,06 dengan perbandingan $F_{\text {hitung }}$ 47,499. Maka dapat diberikan kesimpulan akhir bahwa ketiga variabel yang diujikan pada uji ini menunjukkan hasil positif dan memberikan pengaruh kepada variabel kinerja yang diuji. 


\section{Pengujian Hipotesis SecaraParsial}

Pada uji ini akan menunjukkan nilai pengujian variabel secara parsial (secara tunggal) antara variabel independen terhadap variabel dependen.

\section{Tabel 4.8}

Coefficients $^{\mathrm{a}}$

\section{Uji t}

\begin{tabular}{|ll|r|r|r|r|r|}
\hline \multirow{2}{*}{ Model } & \multicolumn{4}{|c|}{$\begin{array}{c}\text { Standardized } \\
\text { Coefficients }\end{array}$} & \\
\cline { 3 - 5 } & & \multicolumn{2}{|c|}{ Unstandardized Coefficients } & \multicolumn{1}{c|}{ Beta } & \multicolumn{1}{c|}{ Sig. } \\
\hline 1 & (Constant) & .998 & 1.664 & & .600 & .549 \\
& Disiplin & .201 & .060 & .210 & 3.362 & .001 \\
& Stres & .431 & .061 & .451 & 7.014 & .000 \\
& Kompensasi & .295 & .057 & .314 & 5.167 & .000 \\
\hline
\end{tabular}

a. Dependent Variable: Kinerja

Sumber : Hasil Penelitian, 2020 (Data diolah)

Untuk pengambilan nilai dari $t_{\text {tabel }}$ untuk pengujian yaitu dengan $\mathrm{df}=146$ adalah sebesar 1,97635. Berikut ini akan dijelaskan hasil dari uji t :

1. Untuk jumlah pengujian disiplin dengan nilai 3,362 dengan nilai signifikan sebesar 0,001. Nilai t hitung > t tabel atau 3,362 > 1,976, dan signifikansi $<0,05$ maka $\mathrm{H}_{1}$ dinyatakan benar disiplin mempengaruhi terhadap kinerja karyawan di PT. Indofood CBP Sukses Makmur.

2. Untuk jumlah pengujian stres dengan nilai 7,014 dengan nilai signifikan sebesar 0,000. Nilai t hitung > t tabel atau 7,014 > 1,976, dan signifikansi $<0,05$ maka $\mathrm{H}_{2}$ dinyatakan benar stres mempengaruhi terhadap kinerja karyawan di PT. Indofood CBP Sukses Makmur.

3. Untuk hasil pengujian kompensasi dengan nilai 5,167 dengan nilai signifikan sebesar 0,000. Nilai t hitung $>\mathrm{t}$ tabel atau 5,167 > 1,976, dan signifikansi $<0,05$ maka $\mathrm{H}_{3}$ dinyatakan benar kompensasi mempengaruhi terhadap kinerja karyawan di PT. Indofood CBP Sukses Makmur.

\section{Pembahasan Hasil Penelitian}

Setelah melalui seluruh proses penelitian dapat diberikan kesimpulan akhir bahwa hipotesis yang diajukan diawal dinyatakan benar dan menjadi hasil penelitian utama yang telah diajukan kepada perusahaan. Hasil dari penelitian menunjukkan bahwa nilai thitung lebih besar dari $t_{\text {tabel }}(3,362>1,976) . \mathrm{H}_{1}$ dinyatakan benar disiplin mempengaruhi terhadap kinerja karyawan di PT. Indofood CBP Sukses Makmur. Pada penelitian dahulu oleh Khasanah (2016) yang berjudul Pengaruh Kepemimpinan, Disiplin Kerja dan Komunikasi terhadap Kinerja Karyawan (Studi Pada Karyawan Bagian Produksi PT New Merch. Hasil penelitian 
menunjukkan bahwa disiplin berpengaruh positif terhadap kinerja. Kesimpulan akhir dari penelitian ini juga didukung oleh Siagian (2015:305), pendisiplinan pegawai adalah suatu bentuk pelatihan yang berusaha memperbaiki dan membentuk pengetahuan, sikap dan perilaku karyawan sehingga para karyawan tersebut secara sukarela berusaha bekerja secara kooperatif dengan para karyawan yang lain serta meningkatkan prestasi kerjanya.

Setelah melalui seluruh proses penelitian, dapat diberikan kesimpulan akhir bahwa hipotesis yang diajukan diawal dinyatakan benar dan menjadi hasil penelitian utama yang telah diajukan kepada perusahaan. Hasil dari penelitian menunjukkan bahwa nilai thitung lebih besar dari $\mathrm{t}_{\text {tabel }}(7,014>1,976) . \mathrm{H}_{2}$ dinyatakan benar stres mempengaruhi terhadap kinerja karyawan di PT. Indofood CBP Sukses Makmur. Pada penelitian dahulu oleh Luturlean (2018) yang berjudul Pengaruh Stres Kerja dan Beban Kerja Terhadap Kinerja Karyawan di PT Sucofindo Cabang Bandung. Hasil penelitian menunjukkan bahwa stres kerja berpengaruh positif terhadap kinerja. Kesimpulan akhir dari penelitian ini juga didukung oleh Umam (2012:217),tingkat stres yang tinggi atau stress ringan yang berkepanjangan akan menurunkan kinerja karyawan

Setelah melalui seluruh proses penelitian, dapat diberikan kesimpulan akhir bahwa hipotesis yang diajukan diawal dinyatakan benar dan menjadi hasil penelitian utama yang telah diajukan kepada perusahaan. Hasil dari penelitian menunjukkan bahwa nilai $t_{\text {hitung }}$ lebih besar dari $t_{\text {tabel }}(5,167>1,976) . \mathrm{H}_{3}$ dinyatakan benar kompensasi mempengaruhi terhadap kinerja karyawan di PT. Indofood CBP Sukses Makmur. Pada penelitian dahulu oleh Sari (2016) yang berjudul Pengaruh Kompensasi Finansial dan Kompensasi Non Finansial terhadap kinerja karyawan PT. Angkasa Pura. Hasil penelitian menunjukkan bahwa kompensasi berpengaruh positif terhadap kinerja. Kesimpulan akhir dari penelitian ini juga didukung oleh Notoadmodjo (2015:142), kompensasi sangat penting bagi karyawan itu sendiri sebagai individu, karena besarnya kompensasi finansial merupakan pencerminan atau ukuran nilai pekerjaan karyawan itu sendiri. Besar kecilnya kompensasi finansial dapat mempengaruhi kinerja (prestasi kerja), motivasi dan kepuasan kerja karyawan.

Setelah melalui seluruh proses penelitian dapat diberikan kesimpulan akhir bahwa hipotesis yang diajukan diawal dinyatakan benar dan menjadi hasil penelitian utama yang telah diajukan kepada perusahaan. Variabel disiplin, stres dan kompensasi berpengaruh secara bersama-sama terhadap kinerja karyawan. Hasil dari penelitian menunjukkan bahwa nilai $F_{\text {hitung }}$ lebih besar dari $F_{\text {tabel }}(47,499>3,06) . \mathrm{H}_{4}$ dinyatakan benar disiplin, stres dan kompensasimempengaruhi terhadap kinerja karyawan di PT. Indofood CBP Sukses Makmur. 
Hasil dari penelitian ini juga dapat terlihat dari uji koefisien determinasi yang dilakukan dengan memiliki nilai sebesar $48,4 \%$ dan dapat diberikan kesimpulan bahwa variabel disiplin, kompensasi dan stres yang diteliti mempengaruhi variabel kinerja sebesar 48,4\%.

\section{KESIMPULAN}

Hasil pengujian hipotesis secara parsial variabel komunikasidiperoleh nilai $t_{\text {hitung }}>t_{t a b e l}$ atau 6,730>1,99125 dan signifikan yang diperoleh $0,000<0,05$, berarti bahwa secara parsial komunikasiberpengaruh positif dan signifikan. Hasil pengujian hipotesis secara parsial variabel disiplin kerja diperoleh nilai $t_{\text {hitung }}>t_{\text {tabel }}$ atau 2,163>1,99125 dan signifikan yang diperoleh $0,034<0,05$, berarti bahwa secara parsial disiplin kerja berpengaruh positif dan signifikan. Hasil pengujian secara simultan diperoleh nilai $F_{\text {hitung }}(72,231)>F_{\text {tabel }}(3,12)$ dan probabilitas signifikansi $0,000<0,05$. Hasil uji koefisien determinasi menunjukkan $64.3 \%$ dari variasi variabel dependen kinerja karyawan yang dapat dijelaskan oleh variabel independen komunikasi dan disiplin kerja. Dari penelitian ini didapat bahwa variabel yang paling berpengaruh terhadap kinerja karyawan $(\mathrm{Y})$ adalah variabel komunikasi $\left(\mathrm{X}_{1}\right)$ dapat dilihat dari $t_{\text {hitung }}=6,730$ kemudian disusul oleh variabel disiplin $\left(\mathrm{X}_{2}\right) \mathrm{t}_{\text {hitung }}=2,163$.

\section{REFERENSI}

Afandi. Apan. 2016. Human Resource Management. Pustaka Benua.

Bangun, Wilson. 2014. Manajemen Sumber Daya Manusia. Bandung: PT. Gelora Aksara Pratama.

Darmawan, Didit. 2013.Prinsip-prinsip Perilaku Organisasi. Cetakan Pertama, Surabaya: Pena Semesta.

Feriyanto, Andri, Shyta, Endang Triana. 2016. Pengantar Manajemen (3 in 1) Untuk Mahasiswa dan Umum, Cetakan Pertama. Yogyakarta: Mediatera.

Ginting. 2018. Pengaruh Disiplin Kerja dan Komunikasi Terhadap Kinerja Karyawan di PT Sekar Mulia Abadi Medan. Asian Journal of Innovation and Entrepreneurship.

Hartatik, Indah Puji. 2014. Buku Praktis Mengembangkan SDM. Jakarta: Laksana.

Hasibuan, H. Malayu. 2016.Manajemen Sumber Daya Manusia. Edisi Revisi, Jakarta: PT. Bumi Aksara.

Khasanah. 2016. Pengaruh Kepemimpinan, Disiplin Kerja dan Komunikasi terhadap Kinerja Karyawan (Studi Karyawan Pada Bagian Produksi PT New Merch Semarang). Journal of Management. ISSN : 2502 - 7689.

Marwansyah. 2014. Manajemen Sumber Daya Manusia, Edisi Kedua, Alfabeta,. Bandung 
Moeheriono. 2015. Pengukuran Kinerja Berbasis Kompetensi. Edisi Revisi. Jakarta: PT. RajaGrafindo Persada.

Paruru. 2014. Pengaruh Disiplin Kerja dan Kemampuan Kerja Terhadap Kinerja Karyawan PT Air Manado. Jurnal Unsrat.

Rivai, Veithzal dan Ella Jauvani Sagala. 2013. Manajemen Sumber Daya Manusia untuk Perusahaan, Cetakan Keempat, Edisi-2. Jakarta: Rajawali Pers.

Sedarmayanti. 2015. Manajemen Sumber Daya Manusia. Cetakan Ke-7 Penerbit Refika Aditama,Bandung.

Silalahi. Ulber. 2011. Asas Asas Manajemen. Bandung: Refika Aditama

Sinambela, Lijan Poltak. 2016. Kinerja Pegawai Teori Pengukuran dan Implikasi. Cetakan Pertama, Jakarta : PT. Graha Ilmu.

Sugiyono. 2011. Metode Penelitian Kuantitatif dan R\&D. Bandung: CV. Alfabeta.

Sujarweni, V. Wiratna. 2015. Metodologi Penelitian. Yogyakarta: Pustaka Baru Press.

Sunyoto. Danang. 2013. Metodologi Penelitian Akuntansi. Bandung: PT Refika. Aditama

Sutrisno, Edy. 2011. Manajemen Sumber Daya Manusia. Cetakan Pertama, Jakarta: Penerbit Kencana Prenada Group.

Umam, Khaerul. 2012. Perilaku Organisasi. Cetakan ke-2. Bandung: CV. Pustaka Setia. 